\title{
Safety and efficacy study of Ulsant tablet in patients with hyperacidity (Amlapitta)
}

\author{
Nimish Vador ${ }^{1 *}$, Bhavesh Vador ${ }^{2}$ \\ ${ }^{1}$ Dept. of Medical, ${ }^{1}$ Ayurchem Products, Dombivli, Maharashtra, ${ }^{2}$ Yash Clinic and Research Center, Mumbai, Maharashtra, India
}

*Corresponding Author: Nimish Vador

Email: nimishvador@gmail.com

\begin{abstract}
Hyperacidity (Amlapitta) is one of the most common disorder. It is observed by excess production of gastric acid in stomach. It is generally imbalance between offensive parameters like gastric acid and defensive factors like mucin bicarbonate secretions. Over the counter products aim at neutralizing gastric acid rather than the root cause. Ayurvedic preparations has an solution to amlapitta. It not only neutralizes acid secreted but also improves defensive properties of stomach. Once such combination is Ulsant tablets. Acid neutralizing capacity and buffering capacity was conducted in vitro. The aim of the present study was to find out safety and efficacy of Ulsant tablet. In present study total 35 patients were taken. Patients were advised with Ulsant tablet 2 tab twice a day for 45 days. Results shown significant positive results with respect to acid neutralizing capacity, buffering capacity and clinical symptoms.
\end{abstract}

Keywords: Hyperacidity, Ulcer, Ayurveda, Ulsant, Natural.

\section{Introduction}

Amlapitta is considered as one of the common disorder in the entire world. It is the imbalance between the normal physiologic process, leading to decrease in defensive factors and increase in offensive factors. There are many reasons behind the imbalance mainly NSAID (Non-steroidal antiinflammatory drugs), Alcohol, Stress and H pylori infection. Urbanization together with changed lifestyle and intake of unwholesome spicy foods are also one of the cause for gastrointestinal disorders. All the major reasons causes increase in gastric secretions and decrease in gastric mucus secretion. There are two main approaches for treating Hyperacidity (amlapitta). The first deals with reducing the production of gastric acid and the second deals with reenforcing gastric mucosal protection. Antacids and Proton pump inhibitor are widely prescribed medicines. Reports on clinical evaluation show the incidence of relapse and adverse effects like arrthymias, impotence. Many bacterial species do not survive at $\mathrm{pH}$ levels below 4 , hence acidic gastric environment is considered the most important barrier against colonization and infection by ingested bacteria in food we eat. Hence long term acid suppression increases risk of enteric infection and invariably, results in overgrowth of aerobic bacteria. Long term acid suppression may lead to gland atrophy, chronic achlorhydria and risk of gastric cancer leading to more of erosions.

For several decades the adage 'no acid - no ulcer' and drugs used to reduce acid secretion have dominated the pharmacological basis of ulcer therapy. Due to extensive research, treatment for gastric ulcer is now aimed at 'no mucosal damage - no ulcer'. Gastric mucus and mucosal bicarbonate secretion is considered as the most important defense mechanism for the prevention and healing of gastric ulcer. Ayurveda the oldest system of medicine provides leads to find therapeutically useful compounds from plants. It uses extensively time tested herbs in correct combination to treat various diseases. These herbs combination are complex mixtures of compounds and no single compound is thought to provide the desired activity. Some compounds produce the desired therapeutic actions, while others reinforce the same and yet others are considered to neutralize and counteract any possible side effects. The combination of traditional and modern knowledge can produce better drugs to treat hyperacidity and gastric ulcer. One such combination is Ulsant tablets. Ulsant tablets is the combination of key ingredients such as Amalaki, Yashtimadhu, Shatavari, bhringraj, Neem, Gaduchi and others. Hence it was decided to conduct safety and clinical study of the same.

\section{Aims and Objectives}

Safety and Clinical study of Ulsant tablet in patients with Hyperacidity (Amlapitta)

\section{Materials and Methods In-vitro assays}

Acid neutralizing activity: Different concentration of Ulsant tablet was taken, powdered and $70 \mathrm{ml}$ of water was added. After one minute $30 \mathrm{ml}$ of $0.1 \mathrm{~N}$ Hydrochloric acid was added to above solution and mixed for 15 mins. Later $3-5$ drops of phenolphthalein solution is added and mixed. Excess of hydrochloric acid was titrated with $0.1 \mathrm{~N}$ sodium Hydroxide. The moles of acid neutralized is calculated as mentioned in

\section{Buffering capacity}

Ulsant tablet was finely ground and $25 \mathrm{ml}$ of $0.1 \mathrm{~N}$ hydrochloric acid was added with constant stirring. The $\mathrm{pH}$ of the solution was determined at regular interval, till $\mathrm{pH}$ below 2.75 was reached which shows the buffering power of tablet.

\section{Sample size}

35.

\section{Study conducted}

May, 2019 and ended on Sep, 2019.

\section{Study duration}

45 days, Follow up every 15 days till end of the study. 


\section{Drug formulation}

Ulsant Tablets 2 bid.

\section{Site of study}

Yash clinic and research center

Screening and criteria for assessment of patients: Clinical symptoms for assessment

1) Avipaka (Indigestion), 2) Utklesha (Nausea), 3) Vamana (Vomitting), 4) Tiktoamlodgara (Acid eructation), 5) Hritkanthadaha (Heart Burn), 6) Aruchi (Anorexia), 7) Udarashoola (Abdominal pain), 8) klama (tiredness). The assessment progress was noted after every 15 days till 45 days based on the above criteria. Grade points were assigned before and during the treatment as follows:

\begin{tabular}{|l|c|c|}
\hline Severity & Grade & Grade points \\
\hline Normal & G0 & 0 \\
\hline Mild & G1 & 1 \\
\hline Moderate & G2 & 2 \\
\hline Severe & G3 & 3 \\
\hline
\end{tabular}

\section{Inclusion criteria}

1. Age-20 to $60 \mathrm{yrs}$

2. Both sexes

3. Mentally stressed and strained

4. Spicy and oily food in takers

5. Patients with classical symptoms of Amlapitta.

6. Patients who were co-operative and ready give written consent.

\section{Exclusion criteria}

1. Below 20yrs and above 60 yrs

2. Pregnant and lactating

3. Cancer of stomach
4. Cholecystitis

5. Barrett's oesophagus

\section{Statistical assessment of results}

Statistical T -test was applied before and after the treatment. The mean \pm SD before treatment of each sign and symptoms was compared with after 15days, 30 days and 45 days of treatment in each group. $\mathrm{P}$ value $\cdot \mathrm{P}>0.05$ - Not significant or not quite significant $-\mathrm{P}<0.05-$ Significant $-\mathrm{P}<0.01$ Very significant $\bullet P<0.001$ - Highly significant

\section{Results}

Table 1: Acid neutralizing capacity of Ulsant tablet

\begin{tabular}{|l|c|}
\hline $\begin{array}{l}\text { Tablet Concentration in } \\
\text { mg }\end{array}$ & $\begin{array}{c}\text { Acid neutralizing } \\
\text { capacity }\end{array}$ \\
\hline 100 & 23.00 \\
\hline 250 & 23.20 \\
\hline 500 & 24.30 \\
\hline 1000 & 26.20 \\
\hline 1500 & 27.80 \\
\hline
\end{tabular}

Table 2: Buffering capacity of Ulsant tablet

\begin{tabular}{|l|c|}
\hline Time in min & pH \\
\hline 0.0 & 2.44 \\
\hline 0.5 & 2.98 \\
\hline 2.0 & 3.09 \\
\hline 4.0 & 3.40 \\
\hline 6.0 & 3.41 \\
\hline 8.0 & 3.50 \\
\hline $10.0-20.0$ & 2.32 \\
\hline
\end{tabular}

Buffering capacity of Ulsant tablet lies in the range of 10.0 -20.0 minutes.

Table 3: Sex wise distribution

\begin{tabular}{|l|l|}
\hline Sex of Patients & Male $-60 \%$ \\
& Female $-40 \%$ \\
\hline Age & $33 \%$ - Between $20-29$ years \\
& $27 \%$ - Between $30-39$ years \\
& $20 \%$ - Between $40-49$ years 20\% - Between $50-60$ years \\
\hline Area of Living & $57 \%$ - Urban area \\
& $43 \%$ - Rural area \\
\hline Chronicity & $60 \%<2$ year \\
\hline Nature of Udarshoola & $40 \%$ Recurrently burning \\
\hline Family history & $77.5 \%$ Present \\
\hline Habitat & $77.5 \%$ Anupa \\
\hline Nature of work & $37.5 \%$ Service \\
\hline
\end{tabular}

Table 4: Grade wise relief in different sign \& symptoms with Ulsant tablets treatment after 15, 30 and 45 days

\begin{tabular}{|l|l|c|c|c|c|}
\hline S. No. & Sign and Symptoms & \multicolumn{4}{|c|}{ Grading from 0 to 5 (Normal to Severe) } \\
\cline { 3 - 6 } & & $\begin{array}{c}\text { Before } \\
\text { treatment }\end{array}$ & $\begin{array}{c}\text { After treatment 15 } \\
\text { days }\end{array}$ & $\begin{array}{c}\text { After treatment 30 } \\
\text { days }\end{array}$ & $\begin{array}{c}\text { After treatment } \\
\mathbf{4 5} \text { days }\end{array}$ \\
\hline 1 & Avipaka (Indigestion) & 3 & 2 & $1^{*}$ & $0^{*}$ \\
\hline 2 & Klama (Tiredness) & 2 & 1 & $0^{*}$ & $0^{*}$ \\
\hline
\end{tabular}




\begin{tabular}{l|l|c|c|c|c|}
\hline 3 & Utklesha (Nuasea) & 4 & 3 & 2.5 & $1^{*}$ \\
\hline 4 & Vamana (Vomitting) & 3.5 & 2.5 & $1.0^{*}$ & $0^{*}$ \\
\hline 5 & Aruchi (Anorexia) & 4.5 & 4 & 2.5 & $1.5^{*}$ \\
\hline 6 & $\begin{array}{l}\text { Hritkanthadaha (Heart } \\
\text { burn) }\end{array}$ & 5 & 4 & $2.5^{*}$ & $1.5^{*}$ \\
\hline 7 & $\begin{array}{l}\text { Tiktoamlodgara (Acid } \\
\text { Eructation) }\end{array}$ & 5 & 4 & 2 & $1^{*}$ \\
\hline 8 & $\begin{array}{l}\text { Udarashoola } \\
\text { (Abdominal Pain) }\end{array}$ & 4 & 3 & & 2 \\
(*) & Indicates significance as compared to before treatment with $\mathrm{p}<0.05$.
\end{tabular}

Table 5: Showing the percentage of relief in different sign \& symptoms with Ulsant tablets treatment after 15, 30 and 45 days

\begin{tabular}{|l|l|c|c|c|}
\hline $\begin{array}{l}\text { S.No } \\
\mathbf{.}\end{array}$ & Sign and Symptoms & $\begin{array}{c}\text { After treatment 15 } \\
\text { days }\end{array}$ & $\begin{array}{c}\text { After treatment } \\
\mathbf{3 0 ~ d a y s}\end{array}$ & $\begin{array}{c}\text { After treatment 45 } \\
\text { days }\end{array}$ \\
\hline 1 & Avipaka (Indigestion) & 33.33 & 66.66 & 100.00 \\
\hline 2 & Klama (Tiredness) & 50.00 & 100.00 & 100.00 \\
\hline 3 & Utklesha (Nuasea) & 25.00 & 37.50 & 75.00 \\
\hline 4 & Vamana (Vomitting) & 28.57 & 71.52 & 100.00 \\
\hline 5 & Aruchi (Anorexia) & 11.11 & 44.44 & 77.77 \\
\hline 6 & Hritkanthadaha (Heart burn) & 20.00 & 50.00 & 70.00 \\
\hline 7 & Tiktoamlodgara (Acid Eructation) & 20.00 & 50.00 & 70.00 \\
\hline 8 & Udarashoola (Abdominal Pain) & 25.00 & 50.00 & 75.00 \\
\hline $\mathbf{9}$ & Avreage relief in \% & 26.62 & 58.76 & 83.47 \\
\hline
\end{tabular}

\section{Discussion}

As per United States Pharmacopeia (USP) No. 23 minimum acid neutralizing capacity for any antacid should not be less than 5.0. Ulsant tablet shows good Acid neutralizing activity. Acid neutralizing capacity of Ulsant tablets increases with the increase of the dose. Buffering capacity of Ulsant tablets was between $10-20$ mins, which indicates it can keep neutralizing acid secretion upto 20 mins. Thereafter acid secretion would be in normal range.

Out of 35 patients, 30 patients completed the study. Ulsant tablet with the dose of two tablets two times a days showed marked improvement in the paients symptoms like Avipaka, Klama, Utklesha, Vamana, Aruchi, Hridakanthadaha and Udarashoola. Treatment with Ulsant tablet showed average $26.62 \%$ improvement after 15 days, $58.76 \%$ after 30days treatment and $83.47 \%$ after 45 days treatment. All the ingredients of Ulsant tablets are Pittasamaka and Deepan in nature. The unique combination of Ulsant tablets neutralizes excess of gastric acid and regulates further secretion. Ingredients like Yashtimadhu, Shatavari, Nimba stimulates mucin bicarbonate secretions thereby strengthening defensive system. Dhanyak, Kapurkachli and Nishottar normalizes peristalsis and thus prevent reflux esophagitis. Bhringraj and Amlaki are potent antioxidant and anti-inflammatory plants. Guduchi widely known as Amrita is reported to have anti-stress and immunomodulatory activity, which helps in strengthening mucosal defense system.

\section{Conclusion}

The above studies implies that Ulsant tablet can be considered as an effective for treatment of Amlapitta (GERD).

\section{Source of Funding}

None.

\section{Conflict of Interest}

None.

\section{References}

1. Sairam K, Rao ChV, Babu MD, Kumar KV, Agrawal VK, Goel RK. Antiulcerogenic effect of methanolic extract of Emblica officinalis: an experimental study. J Ethnopharmacol. 2002;82(1):1-9.

2. Wittschier N, Faller G, Hensel A. Aqueous extracts and polysaccharides from Liquorice roots (Glycyrrhiza glabra L.) inhibit adhesion of Helicobacter pylori to human gastric mucosa. J Ethnopharmacol. 2009;125(2):218-23.

3. Arveen S, Jagdish S, Kadambari D. Perforated peptic ulcer in South India: an institutional perspective. World $J$ Surg. 2009;33(8):1600-4.

4. Sanduleanu S, Jonkers D, de Bruïne A, Hameeteman W, Stockbrügger RW. Changes in gastric mucosa and luminal environment during acid-suppressive therapy: A review in depth. Dig Liver Dis. 2001;33(8):707-19.

5. Flemström G, Isenberg JI. Gastroduodenal Mucosal Alkaline Secretion and Mucosal Protection. News Physiol Sci. 2001;16:23-9.

6. Kulkarni RD. The Principle of Pharmacology in Ayurveda. Ram Sangam Graphics: Mumbai India; 1998.

7. Sairam K, Priyambada S, Aryya NC, Goel RK. Gastroduodenal ulcer protective activity of Asparagus racemosus: an experimental, biochemical and histological study. J Ethnopharmacol. 2003;86(1):1-10. 
8. Banerjee A, Shrivastava N, Kothari A, Padh H, Nivsarkar M. Antiulcer activity of methanol extract of eclipta alba. Indian $J$ Pharm Sci. 2005;67(2):165-8.

9. Raji Y, Ogunwande IA, Osadebe CA, John G. Effects of Azadirachta indica extract on gastric ulceration and acid secretion in rats. J Ethnopharmacol. 2004;90(1):167-70.

10. Al-Mofleh IA, Alhaider AA, Mossa JS, Al-Sohaibani MO, Rafatullah S, Qureshi S. Protection of gastric mucosal damage by Coriandrum sativum L. pretreatment in Wistar albino rats. Environ Toxicol Pharmacol. 2006;22(1):64-9.

How to cite this article: Vador N, Vador B. Safety and efficacy study of Ulsant tablet in patients with hyperacidity (Amlapitta). Indian J Pharm Pharmacol 2020;7(1):48-51. 